\title{
Correction to: Comparative analysis of ankyrin (ANK) genes of five capripoxviruses isolate strains from Xinjiang province in China
}

\author{
Chuanchuan He ${ }^{1,2}$, Jianjun Tong ${ }^{1,2}$, Xueping Zhang ${ }^{1,3}$, Milikaimu Tuohetiniyazi ${ }^{1,2}, Y_{\text {U Z Zhang }}^{2}$ and Youwen Li ${ }^{1,2,3^{*}}$
}

\section{Correction to: Virology Journal (2020) 17:133 https://doi.org/10.1186/s12985-020-01407- \\ w}

Following the original article [1], it has been raised that tables 5, 6, and 7 in this paper bear many similarities to the tables from [2] (cited as reference 10 in [1]). We want to clarify this point in this correction.

We acknowledge that we followed the same table format used in [2], but the data came from our experiments and were different from data previously reported in [2].

In Table 5 (ANK gene 138), there are eight different nucleotide (nt) mutations, such as nt 1293, 1543, 1896, 1897-1905, and deletion mutations of nt 1895 and 10801082. The amino acid (aa) 631 and its following 3 aa were deleted in our sheeppox virus.

In Table 6 (ANK gene 140), there are an insertion mutation of nt105 and a deletion mutation of nt28, and One aa is missing (10) in our sheeppox virus.

In Table 7 (ANK gene 141.2), there are two more nt mutations than that of Ref.10, such as nt 1253 and 552, and 1 aa was inserted (418) in our sheeppox virus.

We also want to clarify why the results found are similar in our paper [1] and [2]. Firstly, the two papers employed similar methods to investigate the same genes $(138,140,141.2)$ of capripoxvirus strains from their

The original article can be found online at https://doi.org/10.1186/s12985020-01407-w.

*Correspondence: 478520404@qq.com

${ }^{1}$ Key Laboratory of Tarim Livestock Science Technology, Alar 843300 Xinjiang, China

Full list of author information is available at the end of the article respectively different regions: our 6 strains were obtained from Xinjiang, China, while those analyzed in [2] were from India.

Secondly, all of the virus strains in the two papers may come from the same progenitor. China and India are neighboring countries, and Xinjiang shares a direct border with India. According to the ecological evolution of the virus in the geographical environment, it is reasonable to think that the virus found in these two regions comes from the same or similar progenitor, and that they are highly homologous.

Moreover, particularly for capripoxvirus, the genomes from different species are very similar, and the similarity is higher than $96 \%$, and it was even more conserved for the ANK gene.

Full sequencing data (raw data and assembling sequences) are included here as Additional file 1.

\section{Supplementary Information}

The online version contains supplementary material available at https://doi. org/10.1186/s12985-021-01534-y.

Additional file 1. Sequencing results of 3 ANK genes of 6 capripoxviruses isolates in Xinjiang.

\section{Author details}

${ }^{1}$ Key Laboratory of Tarim Livestock Science Technology, Alar 843300, Xinjiang, China. ${ }^{2}$ College of Animal Science, Tarim University, Alar 843300, Xinjiang, China. ${ }^{3}$ College of Life Science, Tarim University, Alar 843300, Xinjiang, China.

Published online: 01 June 2021

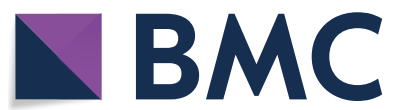

(c) The Author(s) 2021. Open Access This article is licensed under a Creative Commons Attribution 4.0 International License, which permits use, sharing, adaptation, distribution and reproduction in any medium or format, as long as you give appropriate credit to the original author(s) and the source, provide a link to the Creative Commons licence, and indicate if changes were made. The images or other third party material in this article are included in the article's Creative Commons licence, unless indicated otherwise in a credit line to the material. If material is not included in the article's Creative Commons licence and your intended use is not permitted by statutory regulation or exceeds the permitted use, you will need to obtain permission directly from the copyright holder. To view a copy of this licence, visit http://creativecommons.org/licenses/by/4.0/. The Creative Commons Public Domain Dedication waiver (http://creativeco mmons.org/publicdomain/zero/1.0/) applies to the data made available in this article, unless otherwise stated in a credit line to the data. 


\section{References}

1. He C, Tong J, Zhang X, et al. Comparative analysis of ankyrin (ANK) genes of five capripoxviruses isolate strains from Xinjiang province in China. Virol J. 2020;17:133. https://doi.org/10.1186/s12985-020-01407-w.

2. Chaple AR, et al. Genetic studies of terminal regions of vaccine and field isolates of capripoxviruses. Infect Genet Evol. 2019;76:104071.

\section{Publisher's Note}

Springer Nature remains neutral with regard to jurisdictional claims in published maps and institutional affiliations.
Ready to submit your research? Choose BMC and benefit from:

- fast, convenient online submission

- thorough peer review by experienced researchers in your field

- rapid publication on acceptance

- support for research data, including large and complex data types

- gold Open Access which fosters wider collaboration and increased citations

- maximum visibility for your research: over 100M website views per year

At BMC, research is always in progress.

Learn more biomedcentral.com/submissions 